the end that all chemical names shall be understood, because they indicate exact composition?

Purdue University,

LAFAYETTE, IND.

COASTAL SUBSIDENCE IN MASSACHUSETTS

To the Editor of Science: While Professor D. W. Johnson has clearly shown in the November 18 issue of ScIENCE that there are certain factors which produce fictitious appearances of coastal subsidence, chief of which is the irregular height of the tidal wave due to the varying character of the shore, there are a number of marks of subsidence on the Massachusetts coast which it is not probable can be so explained. For example, near Misery Island, Beverly, stumps of forest trees appear in place at a depth of twelve to fourteen feet below low tide.

The striking example given by Professor Johnson of the fictitious appearance of coastal subsidence at Scituate proves also, it seems to me, that subsidence has really been going on. The very fact that the level of the inside marsh was several feet below the outside level of high tide showed how much the land had sunk since the mouth of the North River had been nearly closed. A very similar state of affairs exists in the region of the Norfolk Broads in the eastern part of England. Here, in the same way, the land is slowly sinking, but, owing to the silting up of the mouths of the Yare and the Bure rivers, aided by dyking, the tides have been largely excluded, the marsh has become fresh and has so long ceased to build up that it is below the level of high water outside, and there is danger of the sea breaking through the sand dunes and, as at Scituate, drowning out the region.

Charles W. Townsend

Boston,

December 2, 1910

\section{CALENDAR REFORM}

To the Editor of ScIENCE: I read with interest Professor Chamberlin's suggestions for the reform of the calendar, in the current number of SoIENCE, November 25. It happens that I had thought of a scheme the same as that of Professor Chamberlin in all essential features, but was led to abandon it before publication because I considered that its disadvantages outweighed the advantages.

The advantages of the seasonal division are very slight. The scheme would suit conditions here as well as the present arrangement. In Great Britain, however, the winter begins in November, spring in February, etc. Hence Professor Chamberlin's arrangement with winter beginning in January would not suit conditions and would not be accepted. The earth receives the smallest amount of heat and light at the winter solstice, and neglecting lag this should be midwinter. To call it the beginning of winter as astronomers do, is to allow 45 days lag. To call January 1 the beginning seems to be allowing 55 days lag, not 10 as stated by Professor Chamberlin. This lag varies so much in length with latitude and local conditions that it does not appear that any division of the months into seasons will be universally satisfactory.

The desirability of a year divisible into quarters is unquestioned. But let us see the disadvantages of the scheme. A man who pays rent, for instance, would find his rent due in the first quarter on the first of the month, say. It would be due the Monday of Easter week, on the twenty-second of the month in the second quarter, fifteenth in the third and the eighth in the fourth. Likewise with monthly salaries and, in fact, all business done by the month. A promissory note dated February 15 due in two months would be due April 8, but if due in one month, March 15, or if due in nine months it would be due October 22. If due in eight months, on the first day of Gregorian week. Likewise, in finding the interval in days between two days we should always need to be on guard against omitting or including wrongly one of these weeks. This problem is a very common one in business. Since the suggestion has been made, there will be no difficulty in multiplying these illustrations indefinitely. When we compare this complexity with the simplicity of the same problems in the regular 13 months of 28 
days we see how much is lost. These same objections of course apply, but with less force, to the scheme of Reininghaus, July 29.

Professor Chamberlin's plan would cause the month to be abandoned as a unit of time for business, and force us to use the week or day.

It is true that the same objections may be raised to the 13-month system if we use a quarter as a unit, that is, a quarter from February 15 would be May 22, two quarters, August 1 (assuming the extra month in the middle of the year). But withal this is simpler. Moreover, when we compare the amount of business done by the quarter with that done by the month and day we see which should have the greater consideration in constructing a simple calendar.

I feel sure that these objections could not have occurred to Professor Chamberlin.

Clarkson Schoor of Technology,

Samuel G. Barton

November 29, 1910

\section{INTERNATIONAL CONGRESSES}

To the Editor of Science: At the request of the Swedish geologists the International Geological Congress took place this year instead of 1909. This year was also that in which the International Zoological Congress naturally fell to be held. Since, for the convenience of university workers, these congresses are usually held at the same time of year, and since they, with their excursions, now extend over a considerable period, especially in the case of the Geological Congress, it was almost inevitable that the times of the meetings should clash. This may not affect a large number of participants, but it is rather hard on paleontologists, whose interests lie in both camps, and who, even with the aid of the aeroplane, can not be in two places at once. I should not trouble you with a complaint about what appeared to be inevitable this year, were there not signs of the same difficulty recurring in perpetuity, unless a protest is at once raised. As a matter of fact, the committee of "Paleontologia Universalis," when it met at Stockholm, forwarded to the council of the coungress a request that this interference should be avoided in future. That protest seems to have been without result. If so, in 1913 the paleontologist will again find himself summoned either by duty or desire to opposite quarters of the globe.

\section{F. A. BAther}

\section{SCIENTIFIC BOOKS}

Monograph of the Okapi. By Sir E. RAY LANKESTer, K.C.B., M.A., D.Sc., F.R.S., etc. Atlas (of 48 plates). London, printed by order of the Trustees of the British Museum. 1910. 4to, pp. i-viii, plates 1-48.

Few events of recent years have aroused the interest of naturalists so much as the discovery of the okapi. It was sufficiently surprising that so large and strikingly marked an animal should have remained undiscovered for so many years; that it should prove to be related to a group now extinct increased the interest in the okapi and the known facts relating to it were promptly given in papers of scientific or popular interest, and more comprehensive memoirs were planned by those fortunate enough to be in the way of securing material. Among them was the present monograph, commenced by E. Ray Lankester while he was director of the British Museum and which having been delayed by many causes is a monograph in name only. It consists of 48 plates without text and it is stated in the preface that it is doubtful if the accompanying text will be issued, the need for any having been lessened by the appearance of Fraipont's monograph in 1907, and de Rothschilds and Neuville's paper during the present year, 1910. Fraipont's memoir, by the way, was begun by Forsyth Major, whose interest seems to have flagged after having had a number of illustrations prepared. The plates in Lankester's monograph comprise dorsal, lateral and palatal views of various skulls, drawn on a liberal scale, one third to one half natural size, and these are sufficient to afford good terms of comparison with other material. There are also views of the entire animal including one of a living calf, and plates illustrating variations in the vertebræ. As the explanations of the plates are very full a 